\title{
Value Investing with Firm Size Restrictions: Evidence for the German Stock Market
}

\author{
Lars Kaiser $^{1}$ \\ ${ }^{1}$ Chair in Business Administration, Banking and Financial Management, Institute for Financial Services, \\ University of Liechtenstein, Vaduz, Principality of Liechtenstein \\ Correspondence: Lars Kaiser, University of Liechtenstein, Fürst-Franz-Josef-Strasse, 9490 Vaduz, Principality of \\ Liechtenstein. E-mail: lars.kaiser@uni.li
}

Received: April 2, 2014

Accepted: May 14, 2014

Online Published: May 25, 2014

doi:10.5539/ijef.v6n6p14

URL: http://dx.doi.org/10.5539/ijef.v6n6p14

\begin{abstract}
Recent findings by Fama and French (2012) report a decreasing pattern of value premia alongside an increase in firm size. Large trading volumes of value investors often restrict their investment possibilities to large, liquid stocks and raise a serious issue if large cap value premia are diminishing. Thereon, we test for the existence of value premia with respect to seven fundamental metrics subject to a large cap sample restriction. We provide evidence for the German stock market and observe statistically significant Carhart alphas across all tested value metrics between 1988 until 2012, even after accounting for the total market HML risk factor. Finally, we look at pre- and post-rebalancing months and observe significantly negative value premia before rebalancing and an opposite pattern for past rebalancing returns. Furthermore, we identify calendar effects for value premia when considering a 12-month holding period.
\end{abstract}

Keywords: dax, financial statement analysis, glamour, market efficiency, value

\section{Introduction}

Whilst the existence of a value premium is well excepted, the source of this premium is still subject to discussion. Chan and Lakonishok (2004) summarize three commonly discussed reasons for the existence of a value premium. First of all, Fama and French (1992) argue in line with the efficient market hypothesis in that the superior performance of value stocks is compensation for higher systematic risk. Value stocks are often said to experience stronger financial distress for which investors are compensated by means of a premium. Oertmann (2000) conducts an analysis of the value premium on an international level and confirms this view. Greenwald et al. (2001) amongst others provide a behavioural finance based perspective. They, as well as Lakonishok et al. (1994), argue that investor overconfidence is the driver, as people buy stocks going up in price and vice versa. Given that value stocks have historically experienced low levels of prices they are unfavourable by generally risk averse investors and subsequently dumped. They also tend to show small payoffs and rather slow real growth, which is perceived as 'boring' by investors and for which the market discounts them (Lakonishok et al., 1994). Finally, Kothari et al. (1995) criticise the findings by Fama and French (1992) being subject to methodological issues and a data selection bias, which was later discarded by Chan et al. (1996).

Piotroski and So (2012) provide evidence-based on five metrics: book-to-market, cash-flow-to-price, earnings-to-price, sales growth and equity share turnover-that returns of value, glamour and momentum returns cannot purely be driven by systematic risk, but are "an artefact of predictable expectation errors correlated with past financial data" (Piotroski \& So, 2012, p. 2869). Further light was shed on the characteristics of value and growth portfolios by Chaves and Arnott (2012), who find value portfolios to experience a rebalancing alpha. Rather than outperformance being driven by higher dividend growth, value portfolios chip of low yield stocks and include stocks offering improved yield at every rebalancing, thereby, fostering performance. Au contraire, growth portfolios suffer from a negative rebalancing alpha caused by a significant reduction of dividend growth potential.

Recently, Artmann, Finter and Kempf (2012) look at the specific case of the German stock market and show-in a multivariate Fama and MacBeth (1973) regression-that book-to-market equity, earnings-to-price and momentum are the only factors experiencing explanatory power for cross-sectional stock returns. However, against the general application of book-to-market and price-earnings metrics Hou et al. (2011) find cash-flow-to-price 
factor-mimicking portfolios to do a much better job in capturing the value premium in a global setting. This shows that the metric applied for the construction of value portfolios can lead to significant differences with respect to both asset pricing and general portfolio performance results. Finally, Fama and French (2012) test market, size, value and momentum factors for regional portfolios (North America, Europe, Japan and Asia Pacific) with a specific focus on size patterns. Their results confirm the existence of a size pattern for value portfolios ranked according to book-to-market, earnings-to-price and cash-flow-to-price. Furthermore, their study indicates value premia to decrease in size, where portfolios of large-cap stocks yield value premia significantly below small-cap portfolios.

Based on previous findings, this study takes a closer look at value premia of portfolios ranked according to seven alternative fundamental metrics and subject to a very restricted investment set of large cap stocks in the German stock market. Applying a restricted sample of only the largest thirty companies (DAX-30) by market capitalisation and a simple screening process, we are interested whether a statistically significant difference is observable for value stocks over growth stocks and the leading market index as a whole. We observe statistically significant positive Carhart alphas across all tested metrics. As expected value portfolios load significantly positive on the market factor and significantly negative on the momentum factor. These results are intuitive, given that value portfolios can be seen as contrarian strategies by selling stocks that have historically received a lot of attention and vice versa. Furthermore, we analyse characteristics of value stocks during market up- and downturns and find no clear evidence for the value premium to be driven by higher systematic risk. Finally, we check for rebalancing and calendar effects and report the existence of the 'January effect' for value premia.

The remainder of the paper is structured as follows: Section 2 provides an overview on the sample, data and alternative fundamental metrics applied for the formation of value and growth portfolios. The methodology is specified in Section 3. Finally, Section 4 provides the empirical findings and Section 5 concludes.

\section{Sample, Data and Metrics}

We start of by rebuilding the DAX-30 index, which is the leading German stock market index, according to its actual composition starting with its initiation in 1988. The overall sample period is comprised of 300 monthly observations and ends in December 2012. All data is gathered from Thomson Reuters DataStream. We make use of total return indices for each stock whereby cash and dividend distributions are reinvested. All fundamental metrics are based on annual values as of the last trading day of the year. For the risk decomposition we apply data on Fama-French and momentum factors for the German stock market provided by the Centre of Financial Research Cologne.

An analysis of the German stock market with respect to a large cap constrained investment set proofs particularly interesting in the light of previous research. Most recently Artmann, Finter, Kempf, Koch, and Theissen (2012) analyse the cross section of stock returns and find-consistent with earlier studies by Schlag and Wohlschieß (1997) and Breig and Elsas (2009)-no evidence for a size premium. However, they also suggest that results are very sensitive two the sample period, as studies by Stehle (1997) and Wallmeier (2000) did observe a statistically significant size effect. Furthermore, they show a monthly value premium of $0.60 \%$ per month amongst large cap portfolios. Their results indicate an almost identical value premium of $0.59 \%$ for small cap stocks. Theron, we test for the existence of a value effect subject to a firm size restriction. We do so by only considering the stocks of the German DAX-30 index, which is the leading equity index containing the largest and most liquid firm listed in Germany.

The set of metrics considered for the formation of value and growth portfolios is a selection of the most commonly applied fundamental ratios-e.g., price-to-earnings and book-to-market ratio-as well as some measures of recent attention, including enterprise value-to-EBITDA and dividend growth. The three dividend metrics are particular interesting. Dividend growth (DY) is well established in academic literature and practice, proven to be a valuable fundamental metric for the formation of value portfolios, particular with respect to the wide reaching literature on the 'Dogs of the Dow Strategy' (Rinne \& Vahamaa, 2011). In contrast dividend growth (DG) and payout ratio (POUT) have received increased attention more recently, where the effect of dividend payout is not as clear.

Traditionally, low payout ratios (high retention rate) today have been perceived as a strong indicator of future earnings growth. However, Fama and French (2002, p. 13) show that "more profitable firms have higher dividend payouts" even after controlling for other effects. Their results also indicate higher dividend payout for less volatile, larger stocks. Furthermore, Arnott and Asness (2003) provide robust evidence in-line with Fama and French (2002). Their findings indicate, that low payout ratios are followed by low earnings growth. They argue that managers being confident about the future are happy to payout higher dividends compared to 
pessimistic managers who retain larger parts of their profit.

The relationship between dividend growth, dividend yield (dividend-price ratio) and equity returns is more controversial. Whilst US equity returns are commonly predictable by dividend yield, dividend growth is not (Cochrane, 2008). However, this pattern is subject to the observed time frame, forecasting period and equity market. Campbell and Shiller (1988) show predictability of one year dividend growth by DY prior to 1986 with a negative sign. Ang (2002) comes to the same conclusion but dismisses the relation for longer forecasting periods above one year. More recently Chiang (2008) tests the relation for REITs (real estate investment trusts)-given their favourable dividend policy-and reports DG to be significantly predictable by DY. For a detailed and up-to-date literature overview please refer to Engsted and Pedersen (2009), who find significant predictability for European countries in the 'right direction' i.e., a negative relation. Chaves and Arnott (2012) show that value stocks have a high DY and low DG before rebalancing. They observe that value portfolios show below market average dividend growth rates, of up to 4 years before rebalancing, and growth portfolio above average growth. We argue, based on previous empirical findings, that stocks having experienced consistent historical dividend growth still have low levels of dividend yield, in absolute terms, and are not value firms yet. Thereon, we rank stocks according to their historical 4-year dividend growth rates and define the lower end to be our value portfolios.

Table 1. Categorisation of metrics according to value and growth

\begin{tabular}{|c|c|c|c|c|}
\hline Metric & Abbr. & Value & Growth & Calculation \\
\hline \multirow{2}{*}{ Dividend yield } & \multirow{2}{*}{ DY } & \multirow{2}{*}{ High } & \multirow{2}{*}{ low } & dividend per share (dps) \\
\hline & & & & share price \\
\hline \multirow[t]{2}{*}{ Dividend growth } & \multirow[t]{2}{*}{ DG } & \multirow[t]{2}{*}{ low } & \multirow[t]{2}{*}{ high } & $\frac{\mathrm{dps}_{t}}{-1}$ \\
\hline & & & & $\mathrm{dps}_{t-4}$ \\
\hline \multirow{2}{*}{ Payout ratio } & \multirow{2}{*}{ POUT } & \multirow{2}{*}{ high } & \multirow{2}{*}{ low } & dividends - preferred stock dividends \\
\hline & & & & net income \\
\hline \multirow{2}{*}{ EV/EBITDA } & \multirow{2}{*}{$\mathrm{EV} / \mathrm{E}$} & \multirow{2}{*}{ low } & \multirow{2}{*}{ high } & market value of equity + value of debt - cash \\
\hline & & & & earnings before interest, taxes, depreciation and amortization \\
\hline \multirow{2}{*}{ Book-to-market value } & \multirow{2}{*}{$\mathrm{B} / \mathrm{MV}$} & \multirow{2}{*}{ high } & \multirow{2}{*}{ low } & book value of equity \\
\hline & & & & market value of equity \\
\hline \multirow{2}{*}{ Price/earnings ratio } & \multirow{2}{*}{$\mathrm{P} / \mathrm{E}$} & \multirow{2}{*}{ low } & \multirow{2}{*}{ high } & share price \\
\hline & & & & net income \\
\hline \multirow{2}{*}{ Price/cash flow ratio } & \multirow{2}{*}{$\mathrm{P} / \mathrm{C}$} & \multirow{2}{*}{ low } & \multirow{2}{*}{ high } & share price \\
\hline & & & & cash earnings per share \\
\hline
\end{tabular}

Note. This table provides an overview on the fundamental metrics considered in this study for the formation and analysis of value and growth portfolios. Columns contain the following: (1) metric, (2) abbreviation referred to throughout the rest of the paper, $(3,4)$ association of ranking procedure with respect to a certain metric and both strategies and (5) calculation method to derive respective metric. All metrics are derived on the last trading day of each year for the formation of portfolios for the forthcoming year.

Furthermore, the metrics price-to-cash flow and enterprise value-to-EBITDA (earnings before interest, tax, depreciation and amortization) have received increased attention. There is an ongoing discussion on whether cash flow or EBITDA is a more meaningful measure for investors, in some instances both terms are used interchangeably. To begin with, the term 'cash flow' is not clearly specified and different sources provide alternative definitions, which in turns favours the clear definition of EBITDA. Furthermore, EBITDA provides better comparability across countries and industries as it ignores financing and accounting decisions. For the purpose of ranking stocks Fama and French (2012) state, that "one fundamental (book value, earnings, or cash flow) is pretty much as good as another for this job..." and that "...supplementing BtM with other ratios can in principal improve the information about expected returns.".

We chose to include the price-to-cash earnings ratio rather than actual cash flow. Cash earnings in that respect acts as a proxy for discretionary cash flow (DCF). This offers benefits over free cash flow, which can vary 
heavily depending on capital spending needs. DCF is essentially the remaining capital available for dividend payments, stock repurchases and paying off debt. Subramanyam and Venkatachalam (2007) provide empirical evidence on the superiority of earnings over cash flows for equity valuation.

J. Liu et al. (2007) test cash flow, dividend and earnings for equity valuations and come up with the following ranking: (1) earnings, (2) dividends and (3) cash flow. This holds for the U.S. as well as an international sample. Thereon, we test classical and more recent valuation metrics for the formation of value and growth portfolios for a size restricted subset of the German stock market.

\section{Methodology}

The overall index is composed of the 30 largest firms listed on the German stock exchange according to their market capitalisation, as such we exactly replicate the DAX-30 index between 1988-2012. Every last trading day of the year we rank stocks according to seven metrics presented in Table 1. Thereon, we form equally weighted value and growth portfolios consisting of the ten top and bottom ranked firms. Portfolios are held constant for the following 12-month until the next rebalancing takes place.

Companies being de-listed from the index during the year are liquidated and the proceeds reinvested at the 3-month EURIBOR until the next rebalancing takes place. For the case of firms being bankrupt the procedure is intuitive, with respect to companies being de-listed but are continued to trade we want to exclude any event specific price effects caused by a de-listing. Chandy et al. (2004) provide evidence on the impact of a company's de-listing on its stock price, liquidity and bid-ask spreads. In terms of liquidity and price a significant negative effect is observable, whereas bid-ask spreads tend to increase significantly.

Furthermore, we will split our sample into periods of market up- and downturns. Lakonishok et al. (1994) define market upturns as periods of high ex post market returns and vice versa. This approach was later criticised by Cooper and Gubellini (2011), as results derived from conditional models are very sensitive to the applied conditioning variables (cf., Hwang \& Rubesam, 2013). Alternative approaches-primarily including regime-switching models-exist for the determination of market states. For the purpose of our paper we take a simple approach by defining up- and downturn phases according to positive and negative market returns. Thereon, bear markets are defined as states where returns by the market index are negative and vice versa. We apply the following regressions for deriving alpha and beta values of value portfolios during bear $(d)$ and bull $(u)$ phases:

$$
\begin{aligned}
& r_{p, u, t}-r_{f, t}=\alpha_{u}+\beta_{u}\left(r_{b, u, t}-r_{f, t}\right)+\varepsilon_{u, t} \\
& r_{p, d, t}-r_{f, t}=\alpha_{d}+\beta_{d}\left(r_{b, d, t}-r_{f, t}\right)+\varepsilon_{d, t}
\end{aligned}
$$

Where $\mathrm{r}_{\mathrm{p}, \mathrm{u}, \mathrm{t}}$ is the return of portfolio $\mathrm{p}$ during market upturn $\mathrm{u}$ at time $\mathrm{t}, \mathrm{r}_{\mathrm{b}, \mathrm{u}, \mathrm{t}}$ is the return of benchmark $\mathrm{b}$ and $\mathrm{r}_{\mathrm{f}, \mathrm{t}}$ is the risk-free rate equivalent to the 3-month EURIBOR at time $t$. With respect to the market beta we are particularly interested in observing whether value premia are truly associated to higher systematic risk as suggested by Fama and French (1992); or, if we do in fact observe a value premium puzzle. Methodology is kept consistent when analysing Fama- French and momentum factors where regressions are extended to incorporate size (SMB), value (HML) and momentum (MOM) factors, yielding the following regression equation to derive Carhart alphas $\left(\alpha_{\mathrm{C}}\right)$ :

$$
r_{p, t}-r_{f, t}=\alpha_{C}+\beta_{M K T} \cdot\left(r_{b, t}-r_{f, t}\right)+\beta_{S M B} \cdot S M B_{t}+\beta_{H M L} \cdot H M L_{t}+\beta_{M O M} \cdot M O M_{t}+\varepsilon_{t}
$$

Portfolios are rebalanced on an annual frequency. Whilst common portfolio literature usually applies a monthly rebalancing or optimisation frequency, it is common for value investment strategies to be rebalanced less frequent given the long-term nature of respective strategies. The standard setting in this paper evaluates buy-and-hold portfolios rebalanced on the last calendar day of each year and equally weights stocks to form value and growth strategies. Portfolios are formed on trailing 12-months fundamental metrics at the end of December by means of an equal weighting approach.

The point of rebalancing is subject to discussion. Whilst the calendar year approach is common amongst dividend-yield literature (Domiana et al., 1998; Fama \& French, 1998); alternative papers on fundamentals chose to rebalance half way through the year to ensure that all accounting data for year $\mathrm{t}-1$ is available to form portfolios (Chou et al., 2011; Walkshäusl \& Lobe, 2010; Chou et al., 2011). Chaves and Arnott (2012) go even further and allow for a 12-months reportage lag. In this study we follow the method commonly applied in dividend yield literature-as well as by Lakonishok et al. (1994)-and apply a classical calendar rebalancing approach. 


\section{Results}

This section presents the main empirical findings on the characteristics and risk-adjusted returns for the full sample period between 1988 and 2012, as well as subsamples of bear and bull market phases. We focus on the risk decomposition with respect to the Carhart four-factor model and the argument of the value premium being compensation for higher systematic risk. Finally, we look at the return behaviour around the formation period for both value and growth portfolios to provide evidence on the concept of over optimism for growth and over pessimism for value stocks.

\subsection{Descriptive Statistics}

Portfolio characteristics according to the seven metrics as well as the market-capitalisation weighted DAX-30 index are summarised in Table 2. Panel A reports results for equally weighted value portfolios in annualised terms, in line with our annual rebalancing. We find mean annual returns varying between $15.38 \%$ for $\mathrm{EV} / \mathrm{E}$ and $13.09 \%$ for POUT and B/MV over a period of 25 years relative to $10.53 \%$ for DAX-30. Degrees of excess returns by value strategies above the DAX are reported as ARMA and range between $4.75 \%$ and $1.73 \%$. Interestingly the most popular metrics amongst scholars and practitioners-namely $\mathrm{B} / \mathrm{MV}$ and $\mathrm{P} / \mathrm{E}-$-show lowest excess and risk-adjusted excess returns. This suggests that investors are already exploiting value effects based on these well-known measures. In terms of standard deviation only DG and POUT are below the index. However, in terms of Sharpe ratios (SR) all strategies show preferable results over the benchmark, where EV/E has the highest SR with 0.18 .

Table 2. Descriptive portfolio statistics

\begin{tabular}{|c|c|c|c|c|c|c|c|c|}
\hline & DY & DG & POUT & $\mathrm{EV} / \mathrm{E}$ & $\mathrm{B} / \mathrm{MV}$ & $\mathrm{P} / \mathrm{E}$ & $\mathrm{P} / \mathrm{C}$ & DAX \\
\hline \multicolumn{9}{|c|}{ Panel A - Value portfolios } \\
\hline mean & 14.02 & 13.82 & 13.01 & 15.88 & 13.50 & 12.87 & 15.03 & 10.53 \\
\hline std & 23.16 & 20.84 & 21.13 & 22.63 & 23.70 & 23.79 & 22.30 & 21.64 \\
\hline $\min$ & -23.77 & -22.24 & -27.40 & -20.61 & -23.51 & -24.19 & -21.63 & -25.42 \\
\hline $\max$ & 31.21 & 30.30 & 24.13 & 39.52 & 43.55 & 27.51 & 36.72 & 21.38 \\
\hline sharpe & 0.15 & 0.17 & 0.16 & 0.18 & 0.14 & 0.14 & 0.17 & 0.12 \\
\hline $\mathrm{AR}_{\mathrm{MA}}$ & 3.49 & 3.29 & 2.48 & 5.35 & 2.97 & 2.34 & 4.50 & 0.00 \\
\hline $\mathrm{AR}_{\mathrm{M} 2}$ & 1.91 & 4.24 & 3.04 & 4.12 & 0.99 & 0.39 & 3.71 & 0.00 \\
\hline$\alpha$ & 3.71 & 4.59 & 3.28 & 6.15 & 3.41 & 2.38 & 5.25 & 0.00 \\
\hline$\beta$ & 0.97 & 0.85 & 0.91 & 0.90 & 0.94 & 0.99 & 0.91 & 1.00 \\
\hline$\varnothing$ ratio & 2.52 & -0.13 & 41.27 & 0.97 & 0.74 & 7.68 & -5.06 & 0.00 \\
\hline$\varnothing \mathrm{mv}$ & $11^{\prime} 024$ & $8^{\prime} 400$ & $10^{\prime} 966$ & $9^{\prime} 127$ & $7^{\prime} 527$ & $10^{\prime} 840$ & $9^{\prime} 366$ & $10^{\prime} 538$ \\
\hline \multicolumn{9}{|c|}{ Panel B - Growth portfolios } \\
\hline mean & 11.44 & 11.67 & 10.20 & 8.52 & 9.81 & 11.32 & 8.56 & 10.53 \\
\hline std & 22.70 & 22.34 & 23.53 & 22.27 & 22.36 & 21.45 & 22.70 & 21.64 \\
\hline $\min$ & -26.26 & -24.24 & -23.18 & -28.56 & -32.41 & -30.54 & -31.67 & -25.42 \\
\hline $\max$ & 26.51 & 24.51 & 35.05 & 25.10 & 29.61 & 27.29 & 28.54 & 21.38 \\
\hline sharpe & 0.12 & 0.13 & 0.11 & 0.09 & 0.11 & 0.13 & 0.09 & 0.12 \\
\hline $\mathrm{AR}_{\mathrm{MA}}$ & 0.90 & 1.14 & -0.34 & -2.01 & -0.73 & 0.79 & -1.98 & 0.00 \\
\hline $\mathrm{AR}_{\mathrm{M} 2}$ & 0.00 & 0.51 & -1.66 & -2.40 & -1.25 & 0.96 & -2.61 & 0.00 \\
\hline$\alpha$ & 1.20 & 1.63 & -0.18 & -1.22 & -0.23 & 1.55 & -1.58 & 0.00 \\
\hline$\beta$ & 0.97 & 0.94 & 0.98 & 0.91 & 0.94 & 0.91 & 0.96 & 1.00 \\
\hline$\varnothing$ ratio & 0.68 & 1.14 & 12.62 & 16.56 & 2.94 & 30.12 & 15.11 & 0.00 \\
\hline$\varnothing \mathrm{mv}$ & $11^{\prime} 307$ & $11^{\prime} 483$ & 8'974 & $10^{\prime} 175$ & $12 ' 141$ & $12^{\prime} 684$ & 9’915 & $10^{\prime} 538$ \\
\hline
\end{tabular}

Note. This table reports portfolio statistics for value and growth portfolios ranked according to: dividend yield (DY), 4-years dividend growth (DG), dividend payout ratio (POUT), enterprise value-to-EBITDA (EV/E), book-to-market (B/MV), price-to-earnings (P/E) and price-to-cash earnings. The benchmark, as well as underlying investment set of ranked port- folios, is the leading German equity index DAX-30. Sample size is restricted to 30 largest firm by market cap and value and growth portfolios formed based on the top/bottom ten stocks per metric ranking. Observation period is from January 1988 to December 2012. All portfolios are rebalanced annually on the last trading day of the year. According to Rinne and Vahamaa (2011) we state market-adjusted return as being $A R_{M A}=R_{P}-R_{D A X}$ and Modigliani-squared adjustment as $\mathrm{AR}_{\mathrm{M} 2}=\left(\mathrm{R}_{\mathrm{P}}-\mathrm{R}_{\mathrm{F}}\right) \sigma_{\mathrm{DAX}}-\left(\mathrm{R}_{\mathrm{DAX}}-\mathrm{R}_{\mathrm{F}}\right)$. Values are stated on an annualised basis. 
Panel B of Table 2 reports portfolio statistics of the seven growth portfolios, for comparability reasons. We observe lower mean annual returns compared to their value counterparts with difference ranging between $1.53 \%$ for DG to $6.03 \%$ for EV/E. The low difference with respect to DG portfolios and, consequently, the low value premium is in line with previously mentioned empirical findings on the varying relation between DY, DG and equity returns. Besides we observe positive excess market returns only for DY, DG and P/E, however, not statistically significant. Regarding the average firm size of firms included in value portfolios we find DY, POUT and $\mathrm{P} / \mathrm{E}$ portfolios to include large firms in our sample, whereas, $\mathrm{B} / \mathrm{MV}$ ranked portfolios pick firms with low market capitalisations. This observation is consistent with Lynch (2001), who states that investors optimising portfolios according to return forecasts based on dividend yield experience a shift towards low book-to-market and large market-cap stocks. Also with respect to POUT these finding are consistent with previous literature, as Fama and French (2002) report payout ratios to be higher for large firms.

Taking a closer look at the average metric values for value and growth we observe that investing in firms with negative dividend growth appears to be favourable over positive dividend growth companies. These findings are is in line with previous findings by Chaves and Arnott (2012), however, surprising as this is not just the case for low positive DG but for negative DG as well. However, L. Liu and Zhang (2008) also report negative dividend growth rates for the lower end of momentum portfolios in their U.S. sample, comparable to our value portfolios. Value premia based on DG are only of a small degree compared to the alternative metrics, nevertheless, value portfolios based on DG show highest risk-adjusted returns of $4.50 \%$ per annum in terms of ARM2.

\subsection{Value Premium = Higher Systematic Risk?}

Table 3 provides market betas of value and growth portfolios for both the full sample, as well as bull and bear markets. For the full sample differences vary between 0.00 for DY and 0.11 for DG. In order to argue in favour of higher systematic risk associated to value portfolios we would be looking large differences between value and growth betas, which is not the case for tested metrics besides DG. A clearer picture is observable and ground for discussion when looking at market up- and downturn phases separately.

Table 3. Market phase dependent portfolio beta analysis

\begin{tabular}{lccccccc}
\hline & DY & DG & POUT & EV/E & B/MV & P/E & P/C \\
\hline full sample & & & & & & & \\
value premium & 2.59 & 2.15 & 2.82 & 7.36 & 3.69 & 1.55 & 6.47 \\
value $\beta$ & 0.97 & 0.85 & 0.91 & 0.90 & 0.94 & 0.99 & 0.91 \\
growth $\beta$ & 0.97 & 0.94 & 0.98 & 0.91 & 0.94 & 0.91 & 0.96 \\
bull market & & & & & & & \\
value premium & 2.25 & -2.52 & -0.18 & 9.07 & 5.27 & 5.11 & 5.16 \\
value $\beta$ & 0.95 & 0.84 & 0.85 & 0.93 & 1.01 & 0.97 & 0.95 \\
growth $\beta$ & 1.08 & 0.93 & 1.06 & 0.90 & 0.92 & 0.87 & 0.91 \\
bear market & & & & & & & \\
value premium & 3.10 & 9.16 & 7.32 & 4.79 & 0.66 & -3.79 & 8.44 \\
value $\beta$ & 1.06 & 0.82 & 0.92 & 0.85 & 0.90 & 1.03 & 0.88 \\
growth $\beta$ & 0.91 & 0.95 & 0.94 & 1.00 & 1.05 & 0.98 & 1.05 \\
risk decomposition (full sample) & & & & & & \\
total risk & 23.16 & 20.84 & 21.13 & 22.63 & 23.70 & 23.79 & 22.30 \\
systematic & 22.51 & 17.74 & 19.15 & 20.53 & 22.44 & 23.59 & 20.34 \\
idiosyncratic & 0.66 & 3.10 & 1.97 & 2.10 & 1.26 & 0.20 & 1.96 \\
correlation & 0.91 & 0.89 & 0.87 & 0.89 & 0.93 & 0.87 & 0.89 \\
\hline
\end{tabular}

Note. We report value premia for the full sample between January 1988 and December 2012 and separately for bear and bull markets. We divide market phases according to positive and negative returns observable by the market index. Thereon, bear markets are defined as states where returns by the market index are negative and vice versa. Market betas and correlations are calculated with respect to the DAX-30. Types of risk are stated as annualised percentages.

De Bondt and Thaler (1987) and Chopra et al. (1992) argue against the hypothesis that the value premium is driven by larger systematic risk. They show value betas to be higher during market upturns and lower during market downturn, implying that value carries lower downside risk compared to growth portfolios. These finding where later criticised by Petkova (2005) questioning the behavioural finance perception of value stocks not being 
more risky than growth. Recently Hwang and Rubesam (2013) criticise the findings by Petkova (2005) as being driven by the pre-1963 period as well as non-optimal market phase specifications. Our results are in large parts consistent with Hwang and Rubesam (2013) in that 4/7 value portfolios show higher betas compared to growth portfolios during market upturns. This is true for the exception of the dividend related metrics-DY, DG and POUT-which show lower betas with differences ranging between 0.09 and 0.21 . On the other hand, all but DY and $\mathrm{P} / \mathrm{E}$ show lower betas during market downturns. Concluding, no clear picture is observable for our bet analysis. Theron, we cannot reject the hypothesis of value premia being driven by higher systematic risk.

In a last step we provide a risk decomposition in order to identify whether the smaller degree of diversification by building portfolios of only 10 value stocks leads to increased idiosyncratic risk taking. Indeed, we observe a pattern were a large value premium is accompanied by a larger degree in idiosyncratic risk. In this respect our observations are in-line with previous findings showing that the outperformance of value stocks relates to higher total- and idiosyncratic risk (Li, Brooks, \& Miffre, 2009). One exception is the DG metric, which provides the second lowest value premium of $2.15 \%$ and the highest unsystematic risk of $3.10 \%$ per annum. In terms of correlation we observe highest correlation for the B/MV strategy of 0.93 relative to the DAX-30 index. At the other end, our portfolio sorted according to payout ratio show the lowest correlation of 0.87 ; the ranking and degree is largely in-line with the results reported by Walkhäusl and Lobe (2010) for the S\&P 500.

\subsection{Risk Attribution by Factors}

We adjust returns according to the Carhart (1997) method, based on which we attribute portfolio returns according to the market factor (MKT), size (SMB), book-to-market (HML) and momentum (MOM). We are interested if investors lose out when only considering such a restricted investment set of 30 companies compared to the whole market (MKT) or if the value premium is still existent under such a firm size restriction. Furthermore, by including HML as a risk factor we get insight on the factors capability of capturing the value effect as a whole.

Table 4. Carhart four-factor model risk attribution—value portfolios

\begin{tabular}{|c|c|c|c|c|c|c|c|c|c|c|c|}
\hline & alpha & & MKT & & SMB & & HML & & WML & & $\mathrm{R} 2$ \\
\hline \multicolumn{12}{|c|}{ Panel A - full sample (288 months) } \\
\hline DY & $\begin{array}{l}0.67 \\
(0.16)\end{array}$ & $* * *$ & $\begin{array}{l}1.01 \\
(0.03)\end{array}$ & $* * *$ & $\begin{array}{l}-0.08 \\
(0.05)\end{array}$ & & $\begin{array}{l}0.34 \\
(0.05)\end{array}$ & $* * *$ & $\begin{array}{l}-0.24 \\
(0.04)\end{array}$ & $* * *$ & 0.85 \\
\hline DG & $\begin{array}{l}0.57 \\
(0.16)\end{array}$ & $* * *$ & $\begin{array}{l}0.93 \\
(0.04)\end{array}$ & $* * *$ & $\begin{array}{l}-0.02 \\
(0.05)\end{array}$ & & $\begin{array}{l}0.30 \\
(0.05)\end{array}$ & $* * *$ & $\begin{array}{l}-0.09 \\
(0.04)\end{array}$ & * & 0.81 \\
\hline POUT & $\begin{array}{l}0.48 \\
(0.15)\end{array}$ & $* *$ & $\begin{array}{l}0.99 \\
(0.03)\end{array}$ & $* * *$ & $\begin{array}{l}-0.05 \\
(0.05)\end{array}$ & & $\begin{array}{l}0.16 \\
(0.04)\end{array}$ & $* * *$ & $\begin{array}{l}-0.04 \\
(0.03)\end{array}$ & & 0.85 \\
\hline $\mathrm{EV} / \mathrm{E}$ & $\begin{array}{l}0.73 \\
(0.19)\end{array}$ & $* * *$ & $\begin{array}{l}0.92 \\
(0.04)\end{array}$ & $* * *$ & $\begin{array}{l}-0.17 \\
(0.06)\end{array}$ & $* *$ & $\begin{array}{l}0.36 \\
(0.05)\end{array}$ & $* * *$ & $\begin{array}{l}-0.17 \\
(0.04)\end{array}$ & $* * *$ & 0.80 \\
\hline $\mathrm{B} / \mathrm{MV}$ & $\begin{array}{l}0.64 \\
(0.18)\end{array}$ & $* * *$ & $\begin{array}{l}0.99 \\
(0.04)\end{array}$ & $* * *$ & $\begin{array}{l}-0.05 \\
(0.06)\end{array}$ & & $\begin{array}{l}0.38 \\
(0.05)\end{array}$ & $* * *$ & $\begin{array}{l}-0.27 \\
(0.04)\end{array}$ & $* * *$ & 0.81 \\
\hline $\mathrm{P} / \mathrm{E}$ & $\begin{array}{l}0.54 \\
(0.16)\end{array}$ & $* * *$ & $\begin{array}{l}1.04 \\
(0.03)\end{array}$ & $* * *$ & $\begin{array}{l}-0.03 \\
(0.05)\end{array}$ & & $\begin{array}{l}0.34 \\
(0.04)\end{array}$ & $* * *$ & $\begin{array}{l}-0.23 \\
(0.04)\end{array}$ & $* * *$ & 0.87 \\
\hline $\mathrm{P} / \mathrm{C}$ & $\begin{array}{l}0.70 \\
(0.17)\end{array}$ & $* * *$ & $\begin{array}{l}0.96 \\
(0.04)\end{array}$ & $* * *$ & $\begin{array}{l}-0.07 \\
(0.05)\end{array}$ & & $\begin{array}{l}0.36 \\
(0.05)\end{array}$ & $* * *$ & $\begin{array}{l}-0.20 \\
(0.04)\end{array}$ & $* * *$ & 0.83 \\
\hline \multicolumn{12}{|c|}{ Panel B - bull market (167 months) } \\
\hline DY & $\begin{array}{l}0.68 \\
(0.34)\end{array}$ & $*$ & $\begin{array}{l}0.99 \\
(0.07)\end{array}$ & $* * *$ & $\begin{array}{l}-0.05 \\
(0.07)\end{array}$ & & $\begin{array}{l}0.30 \\
(0.06)\end{array}$ & $* * *$ & $\begin{array}{l}-0.25 \\
(0.05)\end{array}$ & $* * *$ & 0.70 \\
\hline DG & $\begin{array}{l}0.49 \\
(0.34)\end{array}$ & & $\begin{array}{l}0.96 \\
(0.07)\end{array}$ & $* * *$ & $\begin{array}{l}0.06 \\
(0.07)\end{array}$ & & $\begin{array}{l}0.29 \\
(0.06)\end{array}$ & $* * *$ & $\begin{array}{l}-0.13 \\
(0.05)\end{array}$ & $* *$ & 0.63 \\
\hline POUT & $\begin{array}{l}0.74 \\
(0.29)\end{array}$ & * & $\begin{array}{l}0.98 \\
(0.06)\end{array}$ & $* * *$ & $\begin{array}{l}0.03 \\
(0.06)\end{array}$ & & $\begin{array}{l}0.15 \\
(0.05)\end{array}$ & $* *$ & $\begin{array}{l}-0.03 \\
(0.04)\end{array}$ & & 0.67 \\
\hline $\mathrm{EV} / \mathrm{E}$ & $\begin{array}{l}1.05 \\
(0.40)\end{array}$ & $*$ & $\begin{array}{l}0.88 \\
(0.09)\end{array}$ & $* * *$ & $\begin{array}{l}-0.10 \\
(0.08)\end{array}$ & & $\begin{array}{l}0.34 \\
(0.07)\end{array}$ & $* * *$ & $\begin{array}{l}-0.26 \\
(0.06)\end{array}$ & $* * *$ & 0.59 \\
\hline $\mathrm{B} / \mathrm{MV}$ & $\begin{array}{l}0.40 \\
(0.43)\end{array}$ & & $\begin{array}{l}1.04 \\
(0.09)\end{array}$ & $* * *$ & $\begin{array}{l}-0.03 \\
(0.08)\end{array}$ & & $\begin{array}{l}0.42 \\
(0.08)\end{array}$ & $* * *$ & $\begin{array}{l}-0.31 \\
(0.06)\end{array}$ & $* * *$ & 0.64 \\
\hline $\mathrm{P} / \mathrm{E}$ & $\begin{array}{l}0.80 \\
(0.32)\end{array}$ & $*$ & $\begin{array}{l}0.94 \\
(0.07)\end{array}$ & $* * *$ & $\begin{array}{l}-0.11 \\
(0.06)\end{array}$ & * & $\begin{array}{l}0.26 \\
(0.06)\end{array}$ & $* * *$ & $\begin{array}{l}-0.29 \\
(0.04)\end{array}$ & $* * *$ & 0.73 \\
\hline
\end{tabular}




\begin{tabular}{|c|c|c|c|c|c|c|c|c|c|c|c|}
\hline $\mathrm{P} / \mathrm{C}$ & $\begin{array}{l}0.54 \\
(0.37)\end{array}$ & & $\begin{array}{l}1.02 \\
(0.08)\end{array}$ & $* * *$ & $\begin{array}{l}0.01 \\
(0.07)\end{array}$ & & $\begin{array}{l}0.34 \\
(0.07)\end{array}$ & $* * *$ & $\begin{array}{l}-0.23 \\
(0.05)\end{array}$ & $* * *$ & 0.67 \\
\hline \multicolumn{12}{|c|}{ Panel C - bear market (121 months) } \\
\hline DY & $\begin{array}{l}1.14 \\
(0.38)\end{array}$ & $* *$ & $\begin{array}{l}1.07 \\
(0.06)\end{array}$ & $* * *$ & $\begin{array}{l}-0.13 \\
(0.09)\end{array}$ & & $\begin{array}{l}0.37 \\
(0.07)\end{array}$ & $* * *$ & $\begin{array}{l}-0.24 \\
(0.07)\end{array}$ & $* * *$ & 0.79 \\
\hline DG & $\begin{array}{l}0.72 \\
(0.38)\end{array}$ & $*$ & $\begin{array}{l}0.95 \\
(0.06)\end{array}$ & $* * *$ & $\begin{array}{l}-0.14 \\
(0.09)\end{array}$ & * & $\begin{array}{l}0.25 \\
(0.07)\end{array}$ & $* * *$ & $\begin{array}{l}-0.01 \\
(0.07)\end{array}$ & & 0.73 \\
\hline POUT & $\begin{array}{l}0.50 \\
(0.37)\end{array}$ & & $\begin{array}{l}0.96 \\
(0.06)\end{array}$ & $* * *$ & $\begin{array}{l}-0.20 \\
(0.08)\end{array}$ & $*$ & $\begin{array}{l}0.14 \\
(0.07)\end{array}$ & * & $\begin{array}{l}-0.08 \\
(0.06)\end{array}$ & & 0.74 \\
\hline $\mathrm{EV} / \mathrm{E}$ & $\begin{array}{l}0.58 \\
(0.39)\end{array}$ & & $\begin{array}{l}0.93 \\
(0.06)\end{array}$ & $* * *$ & $\begin{array}{l}-0.30 \\
(0.09)\end{array}$ & $* *$ & $\begin{array}{l}0.28 \\
(0.07)\end{array}$ & $* * *$ & $\begin{array}{l}-0.01 \\
(0.07)\end{array}$ & & 0.73 \\
\hline $\mathrm{B} / \mathrm{MV}$ & $\begin{array}{l}0.50 \\
(0.37)\end{array}$ & & $\begin{array}{l}0.99 \\
(0.06)\end{array}$ & $* * *$ & $\begin{array}{l}-0.08 \\
(0.08)\end{array}$ & & $\begin{array}{l}0.29 \\
(0.07)\end{array}$ & $* * *$ & $\begin{array}{l}-0.15 \\
(0.06)\end{array}$ & * & 0.76 \\
\hline $\mathrm{P} / \mathrm{E}$ & $\begin{array}{l}0.88 \\
(0.38)\end{array}$ & * & $\begin{array}{l}1.15 \\
(0.06)\end{array}$ & $* * *$ & $\begin{array}{l}0.08 \\
(0.09)\end{array}$ & & $\begin{array}{l}0.41 \\
(0.07)\end{array}$ & $* * *$ & $\begin{array}{l}-0.19 \\
(0.07)\end{array}$ & ** & 0.80 \\
\hline $\mathrm{P} / \mathrm{C}$ & $\begin{array}{l}0.54 \\
(0.36)\end{array}$ & & $\begin{array}{l}0.93 \\
(0.06)\end{array}$ & $* * *$ & $\begin{array}{l}-0.18 \\
(0.08)\end{array}$ & * & $\begin{array}{l}0.33 \\
(0.07)\end{array}$ & $* * *$ & $\begin{array}{l}-0.11 \\
(0.06)\end{array}$ & * & 0.76 \\
\hline
\end{tabular}

Note. This table reports the results for the risk attribution of value portfolios ranked according to: dividend yield (DY), 4-years dividend growth (DG), dividend payout ratio (POUT), enterprise value-to-EBITDA (EV/E), book-to-market (B/MV), price-to-earnings (P/E) and price-to-cash earnings. Observation period is reduced to January 1988 to December 2011, given the limited data availability for Fama-French and momentum factors. We state coefficients; the intercepts $(\alpha)$ are monthly values, and standard errors in parentheses. Significance levels are denoted by *,** and $* * *$ for $10 \%, 1 \%$ and $0.1 \%$ respectively. We also report adjusted $\mathrm{R}^{2}$ values. The risk factors market (MKT), size (SMB), book-to-market value (HML) and momentum (MOM) are provided by the Centre of Financial Research Cologne.

Panel A of Table 4 examines the value effect controlling for risk factors regarding the full sample period between 1988 to 2011. The sample period had to be reduced by one year for all subsequent analysis due to the unavailability of factor portfolios. We observe value portfolios to significantly load on the market (MKT), value (HML) and momentum (MOM) factors. The size (SML) factor shows negative loading as we would expect given the size bias of the underlying investment set considered for the construction of portfolios, however, only statistically significant at low levels mainly during bear markets. These low negative loadings can be related to the mixed results observed by previous empirical studies regarding the size effect on the German stock market (Artmann, Finter, Kempf, Koch, \& Theissen, 2012). Furthermore, we observe significantly negative loadings on MOM given the nature of value investing as being essentially a contrarian strategy (De Bondt \& Thaler, 1987). This is in line with Houge and Loughran (2006) who also report significantly negative exposure of value portfolios towards MOM and show and increasing pattern amongst large cap portfolios. DG and POUT portfolios once more yield a different pattern compared to the alternative metrics by showing negative but non-significant loadings on MOM, as well as weakest loadings on HML. This deviation from other tested metrics is consistent with our previous market beta analysis, where both show very low market betas during bull markets.

Besides, we are interested in regression intercepts and whether our size restricted value portfolios are capable of generating alpha even after accounting for a value factor in form of book-to- market ratio (HML), as is the standard case of the Fama-French four-factor model. We report significant positive alphas across all tested strategies. Alphas vary between $0.48 \%$ for POUT and $0.73 \%$ per month for EV/E across the full sample. Results indicate, that investors do not suffer from a size restricted investment set to large caps, even when considering $\mathrm{B} / \mathrm{MV}$ as risk factor in itself. This is remarkable as Fama and French (2012) report value premia to decrease along an increase in firm size. A disappearance of the value premium for large cap stocks-as suggested by Fama and French (2012)-implies mispricing to be at the route of value premia. Investors arbitrage these mispricing's away, whereas for small cap and costly stocks limits of arbitrage apply (Schwert, 2003). However, given that we still observe a value premium even for the case of a very restrictive large cap sample brings us back to the risk-based explanation. Similar results have recently been provided by Andrade and Chhaochharia (2012) who also report a large cap value premium for an international data set. Thereon, we take a closer look at sub periods and present results for bull and bear market phases in Panel B and C of Table 4, respectively.

Consistent with the full sample we find almost identical risk factor loadings for both sub periods. All factors significantly load on the market at the $1 \%$ level and loadings on HML are also largely unchanged. WML shows consistent loadings and significance levels for the full sample and bull market; however, loadings shrink during 
bear markets phases. Daniel and Moskowitz (2013) document negatively skewed returns with infrequent but strong and persistent patterns of negative returns for momentum strategies, which they coin 'momentum crashes'. These finding are likely to explain the inconsistency of MOM loadings during market downturns. Besides, SMB is again negative during both market phases. Taking a closer look at intercepts we report an alpha of $0.40 \%$ p.a. for our large cap restricted $\mathrm{B} / \mathrm{MV}$ in bull phases and an alpha of $0.50 \%$ during bear markets. This indicates a concentration on large cap stocks to be favourable in market growth phases, however, we largely lose out on the benefits of diversification across a larger set of stocks when markets decline.

With respect to the three dividend related metrics (DY, DG and POUT) we observe very different patterns. DY portfolios show significant alphas varying between $0.68 \%$ and $1.14 \%$ for bull and bear phases, respectively. This is in favour of the common perception and practitioner's proclamation of high dividend yielding stocks being a favourable hedge during market downturns. On the other hand DG performs relatively poor during bull markets with an alpha of $0.49 \%$ p.m. compared to the best cross metric performance of $1.05 \%$ for EV/E. POUT yields the lowest Carhart alpha across all metrics of $0.50 \%$ during market downturns. Nance et al. (1993) argue that firms can reduce the likelihood of financial distress by maintaining a strong liquidity position by either reducing their payout ratio or increasing their holdings of cash and cash equivalents. Therefore, portfolios of firms with high payout ratios are more likely to experience financial distress and, therefore, perform worse during market downturns.

Next we turn to growth portfolios and their risk decomposition, presented in Table 5. Although focus of this paper is on the value side, we provide results and short discussion for completeness. As for L. Liu and Zhang (2008) we show higher factor loadings for value portfolios compared to growth portfolios. We observe significant positive alphas for growth portfolios-although at low levels-varying between $0.25 \% \mathrm{for} \mathrm{P} / \mathrm{C}$ and $0.45 \%$ for DG across the full sample. As for the value portfolios we observe significant market betas across all market phases and metrics. With respect to the size factor we find negative loadings for all but EV/E at low significance levels. Against our expectation loadings on the momentum factor are, as for value portfolios, also negative and for the case of DG, POUT and EV/E statistically significant at the $99.9 \%$ level.

High return spreads between value and growth portfolios with respect to price-to-cash earnings, which we set as a proxy for cash flow, are in line with earlier results by Chan et al. (1991) and Lakonishok et al. (1994); where high ratios of cash-flow-to-price indicate higher future equity returns. In this context our measure for cash flow only marginally deviates from previous studies where Lakonishok et al. (1994) define 'cash flow' as earnings plus depreciation whereas we make use of 'cash earnings' defined as net income plus depreciation and amortisation. Although firms can show growing cash earnings whilst operating cash flows are lagging behind thereby increasing the risk of future write downs - it should still be a fair proxy (Mulford \& Jayko, 2007).

Table 5. Carhart four-factor model risk attribution—growth portfolios

\begin{tabular}{|c|c|c|c|c|c|c|c|c|c|c|c|}
\hline & alpha & & MKT & & SMB & & HML & & WML & & $\mathrm{R} 2$ \\
\hline \multicolumn{12}{|c|}{ Panel A - full sample (288 months) } \\
\hline DY & $\begin{array}{l}0.43 \\
(0.17)\end{array}$ & $*$ & $\begin{array}{l}1.05 \\
(0.04)\end{array}$ & $* * *$ & $\begin{array}{l}-0.07 \\
(0.05)\end{array}$ & & $\begin{array}{l}-0.03 \\
(0.05)\end{array}$ & & $\begin{array}{l}-0.06 \\
(0.04)\end{array}$ & & 0.84 \\
\hline DG & $\begin{array}{l}0.45 \\
(0.16)\end{array}$ & $* *$ & $\begin{array}{l}0.98 \\
(0.03)\end{array}$ & $* * *$ & $\begin{array}{l}-0.11 \\
(0.05)\end{array}$ & * & $\begin{array}{l}0.24 \\
(0.04)\end{array}$ & $* * *$ & $\begin{array}{l}-0.19 \\
(0.04)\end{array}$ & $* * *$ & 0.85 \\
\hline POUT & $\begin{array}{l}0.42 \\
(0.16)\end{array}$ & * & $\begin{array}{l}1.01 \\
(0.03)\end{array}$ & $* * *$ & $\begin{array}{l}-0.13 \\
(0.05)\end{array}$ & $*$ & $\begin{array}{l}0.14 \\
(0.05)\end{array}$ & ** & $\begin{array}{l}-0.23 \\
(0.04)\end{array}$ & $* * *$ & 0.85 \\
\hline $\mathrm{EV} / \mathrm{E}$ & $\begin{array}{l}0.38 \\
(0.17)\end{array}$ & $*$ & $\begin{array}{l}1.03 \\
(0.04)\end{array}$ & $* * *$ & $\begin{array}{l}0.11 \\
(0.06)\end{array}$ & $*$ & $\begin{array}{l}0.08 \\
(0.05)\end{array}$ & $*$ & $\begin{array}{l}-0.18 \\
(0.04)\end{array}$ & $* * *$ & 0.82 \\
\hline $\mathrm{B} / \mathrm{MV}$ & $\begin{array}{l}0.37 \\
(0.18)\end{array}$ & $*$ & $\begin{array}{l}1.00 \\
(0.04)\end{array}$ & $* * *$ & $\begin{array}{l}-0.10 \\
(0.06)\end{array}$ & $*$ & $\begin{array}{l}-0.07 \\
(0.05)\end{array}$ & & $\begin{array}{l}-0.07 \\
(0.04)\end{array}$ & * & 0.80 \\
\hline $\mathrm{P} / \mathrm{E}$ & $\begin{array}{l}0.39 \\
(0.16)\end{array}$ & $*$ & $\begin{array}{l}0.96 \\
(0.04)\end{array}$ & $* * *$ & $\begin{array}{l}-0.16 \\
(0.05)\end{array}$ & $* *$ & $\begin{array}{l}-0.01 \\
(0.05)\end{array}$ & & $\begin{array}{l}-0.03 \\
(0.04)\end{array}$ & & 0.82 \\
\hline $\mathrm{P} / \mathrm{C}$ & $\begin{array}{l}0.25 \\
(0.18)\end{array}$ & & $\begin{array}{l}1.03 \\
(0.04)\end{array}$ & $* * *$ & $\begin{array}{l}-0.06 \\
(0.06)\end{array}$ & & $\begin{array}{l}-0.02 \\
(0.05)\end{array}$ & & $\begin{array}{l}-0.09 \\
(0.04)\end{array}$ & $*$ & 0.81 \\
\hline \multicolumn{12}{|c|}{ Panel B - bull market (167 months) } \\
\hline DY & $\begin{array}{l}-0.13 \\
(0.35)\end{array}$ & & $\begin{array}{l}1.18 \\
(0.08)\end{array}$ & $* * *$ & $\begin{array}{l}-0.03 \\
(0.07)\end{array}$ & & $\begin{array}{l}0.00 \\
(0.06)\end{array}$ & & $\begin{array}{l}-0.07 \\
(0.05)\end{array}$ & & 0.70 \\
\hline DG & 0.60 & * & 0.91 & $* * *$ & -0.18 & $* *$ & 0.23 & $* * *$ & -0.21 & $* * *$ & 0.70 \\
\hline
\end{tabular}




\begin{tabular}{|c|c|c|c|c|c|c|c|c|c|c|c|}
\hline & $(0.32)$ & & $(0.07)$ & & $(0.06)$ & & $(0.06)$ & & $(0.04)$ & & \\
\hline POUT & $\begin{array}{l}0.27 \\
(0.37)\end{array}$ & & $\begin{array}{l}1.04 \\
(0.08)\end{array}$ & $* * *$ & $\begin{array}{l}-0.13 \\
(0.07)\end{array}$ & $*$ & $\begin{array}{l}0.11 \\
(0.07)\end{array}$ & $*$ & $\begin{array}{l}-0.27 \\
(0.05)\end{array}$ & $* * *$ & 0.69 \\
\hline $\mathrm{EV} / \mathrm{E}$ & $\begin{array}{l}0.61 \\
(0.39)\end{array}$ & & $\begin{array}{l}0.93 \\
(0.08)\end{array}$ & $* * *$ & $\begin{array}{l}0.03 \\
(0.07)\end{array}$ & & $\begin{array}{l}0.07 \\
(0.07)\end{array}$ & & $\begin{array}{l}-0.16 \\
(0.05)\end{array}$ & $* *$ & 0.56 \\
\hline $\mathrm{B} / \mathrm{MV}$ & $\begin{array}{l}1.05 \\
(0.40)\end{array}$ & $* *$ & $\begin{array}{l}0.80 \\
(0.09)\end{array}$ & $* * *$ & $\begin{array}{l}-0.19 \\
(0.08)\end{array}$ & $*$ & $\begin{array}{l}-0.17 \\
(0.07)\end{array}$ & $*$ & $\begin{array}{l}-0.08 \\
(0.05)\end{array}$ & & 0.53 \\
\hline $\mathrm{P} / \mathrm{E}$ & $\begin{array}{l}0.84 \\
(0.37)\end{array}$ & * & $\begin{array}{l}0.84 \\
(0.08)\end{array}$ & $* * *$ & $\begin{array}{l}-0.20 \\
(0.07)\end{array}$ & $* *$ & $\begin{array}{l}0.01 \\
(0.07)\end{array}$ & & $\begin{array}{l}-0.02 \\
(0.05)\end{array}$ & & 0.55 \\
\hline $\mathrm{P} / \mathrm{C}$ & $\begin{array}{l}0.71 \\
(0.41)\end{array}$ & * & $\begin{array}{l}0.88 \\
(0.09)\end{array}$ & $* * *$ & $\begin{array}{l}-0.14 \\
(0.08)\end{array}$ & $*$ & $\begin{array}{l}-0.01 \\
(0.07)\end{array}$ & & $\begin{array}{l}-0.09 \\
(0.06)\end{array}$ & & 0.52 \\
\hline \multicolumn{12}{|c|}{ Panel C - bear market (121 months) } \\
\hline DY & $\begin{array}{l}0.16 \\
(0.39)\end{array}$ & & $\begin{array}{l}1.00 \\
(0.06)\end{array}$ & $* * *$ & $\begin{array}{l}-0.09 \\
(0.09)\end{array}$ & & $\begin{array}{l}-0.07 \\
(0.07)\end{array}$ & & $\begin{array}{l}0.02 \\
(0.07)\end{array}$ & & 0.71 \\
\hline DG & $\begin{array}{l}0.69 \\
(0.39)\end{array}$ & $*$ & $\begin{array}{l}1.05 \\
(0.06)\end{array}$ & $* * *$ & $\begin{array}{l}-0.02 \\
(0.09)\end{array}$ & & $\begin{array}{l}0.25 \\
(0.07)\end{array}$ & $* * *$ & $\begin{array}{l}-0.17 \\
(0.07)\end{array}$ & * & 0.74 \\
\hline POUT & $\begin{array}{l}0.34 \\
(0.35)\end{array}$ & & $\begin{array}{l}1.02 \\
(0.06)\end{array}$ & $* * *$ & $\begin{array}{l}-0.11 \\
(0.08)\end{array}$ & & $\begin{array}{l}0.15 \\
(0.06)\end{array}$ & $*$ & $\begin{array}{l}-0.16 \\
(0.06)\end{array}$ & * & 0.78 \\
\hline $\mathrm{EV} / \mathrm{E}$ & $\begin{array}{l}1.07 \\
(0.36)\end{array}$ & $* *$ & $\begin{array}{l}1.14 \\
(0.06)\end{array}$ & $* * *$ & $\begin{array}{l}0.20 \\
(0.08)\end{array}$ & $*$ & $\begin{array}{l}0.14 \\
(0.07)\end{array}$ & $*$ & $\begin{array}{l}-0.29 \\
(0.06)\end{array}$ & $* * *$ & 0.80 \\
\hline $\mathrm{B} / \mathrm{MV}$ & $\begin{array}{l}1.04 \\
(0.38)\end{array}$ & $* *$ & $\begin{array}{l}1.12 \\
(0.06)\end{array}$ & $* * *$ & $\begin{array}{l}-0.01 \\
(0.09)\end{array}$ & & $\begin{array}{l}0.06 \\
(0.07)\end{array}$ & & $\begin{array}{l}-0.18 \\
(0.07)\end{array}$ & $* *$ & 0.77 \\
\hline $\mathrm{P} / \mathrm{E}$ & $\begin{array}{l}0.84 \\
(0.35)\end{array}$ & $*$ & $\begin{array}{l}1.03 \\
(0.06)\end{array}$ & $* * *$ & $\begin{array}{l}-0.17 \\
(0.08)\end{array}$ & $*$ & $\begin{array}{l}-0.02 \\
(0.07)\end{array}$ & & $\begin{array}{l}-0.10 \\
(0.06)\end{array}$ & & 0.77 \\
\hline $\mathrm{P} / \mathrm{C}$ & $\begin{array}{l}0.89 \\
(0.37)\end{array}$ & * & $\begin{array}{l}1.14 \\
(0.06)\end{array}$ & $* * *$ & $\begin{array}{l}-0.01 \\
(0.09)\end{array}$ & & $\begin{array}{l}-0.01 \\
(0.07)\end{array}$ & & $\begin{array}{l}-0.16 \\
(0.07)\end{array}$ & $*$ & 0.78 \\
\hline
\end{tabular}

Note. This table reports the results for the risk attribution of value portfolios ranked according to: dividend yield (DY), 4-years dividend growth (DG), dividend payout ratio (POUT), enterprise value-to-EBITDA (EV/E), book-to-market (B/MV), price-to-earnings (P/E) and price-to-cash earnings. Observation period is reduced to January 1988 to December 2011, given the limited data availability for Fama-French and momentum factors. We state coefficients; the intercepts $(\alpha)$ are monthly values, and standard errors in parentheses. Significance levels are denoted by $* * *$ and $* * *$ for $10 \%, 1 \%$ and $0.1 \%$ respectively. We also report adjusted $\mathrm{R} 2$ values. The risk factors market (MKT), size (SMB), book-to-market value (HML) and momentum (MOM) are provided by the Centre of Financial Research Cologne.

We show that Fama-French and momentum factors can explain large parts of size restricted large-cap value portfolio returns ranked according to alternative metrics. The underlying portfolio characteristics appear to vary strongly between tested metrics from DY portfolios providing stable returns during market up- and downturns to DG portfolios appearing to be a bear market hedge. However, some metrics still show statistically significant alphas after accounting for risk factors even when the sample is restricted to large caps, which raises the question on whether the Fama-French HML factor - based on book-to-market equity - is the best choice to capture the value premium in stock returns.

\subsection{Calendar and Rebalancing Effects}

Furthermore, we take a closer look at the pre- and post-portfolio composition of value versus growth portfolios. We are interested in three main aspects. First of all, are value premia significantly negative for the 12-month prevailing rebalancing and positive 12-month after? Secondly, do we observe seasonality in value premia? Chou et al. (2011) document a significant 'January effect' for large cap value premia in the U.S. stock market, driven by loser stocks at the end of the year. Furthermore, we also look at cross-metric consistency of our findings and report an approximately $55 \%$ change in portfolio composition per year. 
Table 6. Average monthly value premia 12-month pre- and post-rebalancing

\begin{tabular}{|c|c|c|c|c|c|c|c|c|c|c|c|c|c|c|c|}
\hline & DY & & DG & & POUT & & $\mathrm{EV} / \mathrm{E}$ & & $\mathrm{B} / \mathrm{MV}$ & & $\mathrm{P} / \mathrm{E}$ & & $\mathrm{P} / \mathrm{C}$ & & mean \\
\hline \multicolumn{16}{|c|}{ Panel A1: Monthly returns before rebalancing } \\
\hline-11 & $(1.21)$ & $* *$ & 0.33 & & 0.92 & $*$ & 0.96 & * & $(1.25)$ & ** & $(1.49)$ & $* * *$ & $(0.57)$ & & $(0.33)$ \\
\hline-10 & $(1.20)$ & $* *$ & $(0.97)$ & $* *$ & $(0.45)$ & & 0.09 & & $(1.09)$ & $* *$ & $(0.10)$ & & $(0.37)$ & & $(0.58)$ \\
\hline-9 & $(1.44)$ & $* * *$ & 0.83 & * & $(0.44)$ & & 0.58 & & $(0.30)$ & & 0.44 & & $(0.79)$ & $*$ & $(0.16)$ \\
\hline-8 & $(1.32)$ & $* *$ & 0.27 & & $(0.96)$ & & $(0.39)$ & & $(0.55)$ & & $(0.78)$ & & $(0.54)$ & & $(0.61)$ \\
\hline-7 & $(0.28)$ & & $(0.67)$ & $*$ & 0.41 & & $(0.03)$ & & $(1.08)$ & $* * *$ & 0.09 & & $(0.96)$ & $* *$ & $(0.36)$ \\
\hline-6 & $(2.23)$ & $* * *$ & $(0.40)$ & & 0.00 & & $(0.08)$ & & (1.39) & $* * *$ & $(1.58)$ & $* * *$ & 0.33 & & $(0.76)$ \\
\hline-5 & $(1.33)$ & $* *$ & 1.33 & $* * *$ & 0.22 & & 0.05 & & 0.01 & & $(1.37)$ & $* *$ & 0.42 & & $(0.10)$ \\
\hline-4 & $(0.89)$ & & 0.27 & & 0.38 & & 0.12 & & $(0.72)$ & & (1.39) & $* *$ & $(0.26)$ & & $(0.36)$ \\
\hline-3 & $(3.45)$ & $* * *$ & 0.33 & & 0.45 & & $(1.58)$ & $* *$ & $(2.38)$ & $* * *$ & $(2.93)$ & $* * *$ & (1.62) & $* *$ & (1.60) \\
\hline-2 & $(1.63)$ & $* *$ & 0.19 & & $(0.29)$ & & 0.82 & & $(2.05)$ & $* * *$ & $(1.57)$ & $* *$ & $(1.21)$ & $*$ & $(0.82)$ \\
\hline-1 & $(0.21)$ & & $(1.17)$ & $* *$ & 1.84 & $* * *$ & $(0.60)$ & & $(2.14)$ & $* * *$ & $(1.80)$ & $* * *$ & $(1.43)$ & $* * *$ & $(0.79)$ \\
\hline 0 & 0.38 & & $(0.38)$ & & 1.65 & $* * *$ & 1.72 & $* * *$ & (1.16) & $* * *$ & $(0.09)$ & & $(0.65)$ & & 0.21 \\
\hline \multicolumn{16}{|c|}{ Panel A2: Monthly returns after rebalancing } \\
\hline 1 & $(0.23)$ & & 1.77 & $* * *$ & 0.17 & & 1.34 & $* *$ & 0.19 & & 0.08 & & 1.56 & $* * *$ & 0.70 \\
\hline 2 & $(0.12)$ & & $(1.06)$ & $* *$ & $(0.33)$ & & 0.62 & & $(0.12)$ & & 0.19 & & 0.11 & & $(0.10)$ \\
\hline 3 & 0.07 & & 0.64 & & $(1.60)$ & $* * *$ & 1.40 & $* * *$ & 1.57 & $* * *$ & 0.00 & & 0.93 & $*$ & 0.43 \\
\hline 4 & 0.26 & & 0.64 & & $(0.33)$ & & 0.26 & & 0.91 & & 1.55 & $* * *$ & 0.46 & & 0.54 \\
\hline 5 & 0.38 & & $(0.10)$ & & 0.45 & & 0.22 & & $(0.26)$ & & 0.80 & $* *$ & 0.09 & & 0.23 \\
\hline 6 & $(0.46)$ & & 0.56 & & $(0.07)$ & & 0.13 & & $(0.05)$ & & $(0.62)$ & & 0.88 & $* *$ & 0.05 \\
\hline 7 & 0.38 & & 0.13 & & 0.17 & & 0.96 & * & 1.69 & $* * *$ & 0.12 & & 0.85 & & 0.62 \\
\hline 8 & 0.75 & & 0.92 & $*$ & 0.78 & & 0.11 & & 0.39 & & 0.01 & & 0.90 & & 0.55 \\
\hline 9 & $(0.73)$ & & $(0.01)$ & & 0.86 & & $(1.15)$ & & $(0.41)$ & & $(1.39)$ & $*$ & $(0.45)$ & & $(0.47)$ \\
\hline 10 & $(0.88)$ & & $(0.29)$ & & 0.12 & & 0.99 & & $(0.62)$ & & $(1.39)$ & $* *$ & 0.90 & & $(0.17)$ \\
\hline 11 & 1.31 & $* *$ & $(1.20)$ & $* * *$ & 2.04 & $* * *$ & 0.41 & & $(1.00)$ & $* *$ & 0.28 & & $(0.51)$ & & 0.19 \\
\hline 12 & 1.86 & $* * *$ & 0.14 & & 0.58 & & 2.06 & $* * *$ & 1.40 & $* * *$ & 1.92 & $* * *$ & 0.74 & $*$ & 1.24 \\
\hline \multicolumn{16}{|c|}{ Panel A3: Average pre- and post-rebalancing returns } \\
\hline pre & $(1.23)$ & & 0.00 & & 0.31 & & 0.14 & & $(1.18)$ & & $(1.05)$ & & $(0.64)$ & & $(0.52)$ \\
\hline post & 0.22 & & 0.18 & & 0.23 & & 0.61 & & 0.31 & & 0.13 & & 0.54 & & 0.32 \\
\hline diff & 1.45 & $* * *$ & 0.18 & * & $(0.08)$ & & 0.48 & $* * *$ & 1.48 & $* * *$ & 1.18 & $* * *$ & 1.18 & $* * *$ & 0.84 \\
\hline \multicolumn{16}{|c|}{ Panel B: Portfolio reallocation (per year) } \\
\hline value & 0.58 & & 0.59 & & 0.59 & & 0.50 & & 0.53 & & 0.66 & & 0.47 & & 0.56 \\
\hline growth & 0.57 & & 0.65 & & 0.59 & & 0.56 & & 0.50 & & 0.65 & & 0.58 & & 0.59 \\
\hline diff & 0.01 & & $(0.06)$ & $* * *$ & 0.00 & & $(0.06)$ & $* * *$ & 0.03 & & 0.01 & & $(0.11)$ & $* * *$ & $(0.03)$ \\
\hline
\end{tabular}

Note. This table reports average returns on a monthly basis for the 12-month pre- and post-rebalancing of value portfolios ranked according to: dividend yield (DY), 4-years dividend growth (DG), dividend payout ratio (POUT), enterprise value-to-EBITDA (EV/E), book-to-market (B/MV), price-to-earnings (P/E) and price-to-cash earnings. Observation period is from January 1988 to December 2011, to be consistent with previous analysis. For clarity we state negative average monthly returns in parentheses. Rebalancing takes place on December 31 of each year, which corresponds to the end of period 0 in this table. Significance levels are denoted by $*, * *$ and $* * *$ for $10 \%, 1 \%$ and $0.1 \%$ respectively.

Given the documented existence of a value premium implies that value stocks should show below growth portfolio returns ex-ante formation and outperform growth portfolios ex-post. Table 6 reports value premia, across all seven considered metrics, for 12-months pre-rebalancing (formation period) and 12-month post-rebalancing (holding period). In the case of 2012 we rebalance on December 31 according to the trailing 12-month metric. Thereon, we look back what the portfolio returns would have been given this composition between January (-11) and December (0) 2012 compared to the actual portfolio performance subsequent to rebalancing from January $(+1)$ to December $(+12)$ 2013. For clarity we indicate negative value premia in parenthesis.

We observe a clear pattern of cross metric averages being negative for the pre-rebalancing period. Monthly value premia before rebalancing vary between $-0.10 \%$ in May and $1.60 \%$ in September. On a single metric basis, the well-established metrics DY, B/MV and P/E show the clearest pattern in terms of $2 / 3$ of the months being statistically significant negative. For the post-rebalancing period we observe significant positive value premia 
across all metrics, with positive mean value premia varying between $0.05 \%$ in June and $1.24 \%$ in December. Bottom row of Table 6 states differences between average pre- and post-rebalancing returns. We present significantly higher value premia for the post-rebalancing period across all metrics but POUT. We document significantly positive value premia for POUT of $1.84 \%$ in November and $1.65 \%$ in December, prior to rebalancing. These findings are in-line with the traditional view of high retention rates (low dividend payout) being an indicator for future earnings growth and questions the observations by Arnott and Asness (2003).

In a next step, we check for seasonality in value premia. Chou et al. (2011) report a significant January effect in value premia increasing in strength alongside an increase in firm size. Focusing on their results with respect to large cap stocks, they report a significant value premium at the 5\% level of $2.07 \%$ in January. They also find non-significant negative returns for the summer months - being May, June and July - as well as October and November. Their explanation regarding the January effect is based on the window-dressing hypothesis, according to which institutional investors aim to increase their portfolios attractiveness towards the end of the year by selling loser and buying winner stocks. This causes downward price pressure on loser stocks in December and causes higher returns in January where price pressure ceases (Chou et al., 2011). More precisely they observe value premia on large cap stocks to be concentrated on the first ten trading days in January, however, an increasing tendency is observable already on the last 10 trading days of December.

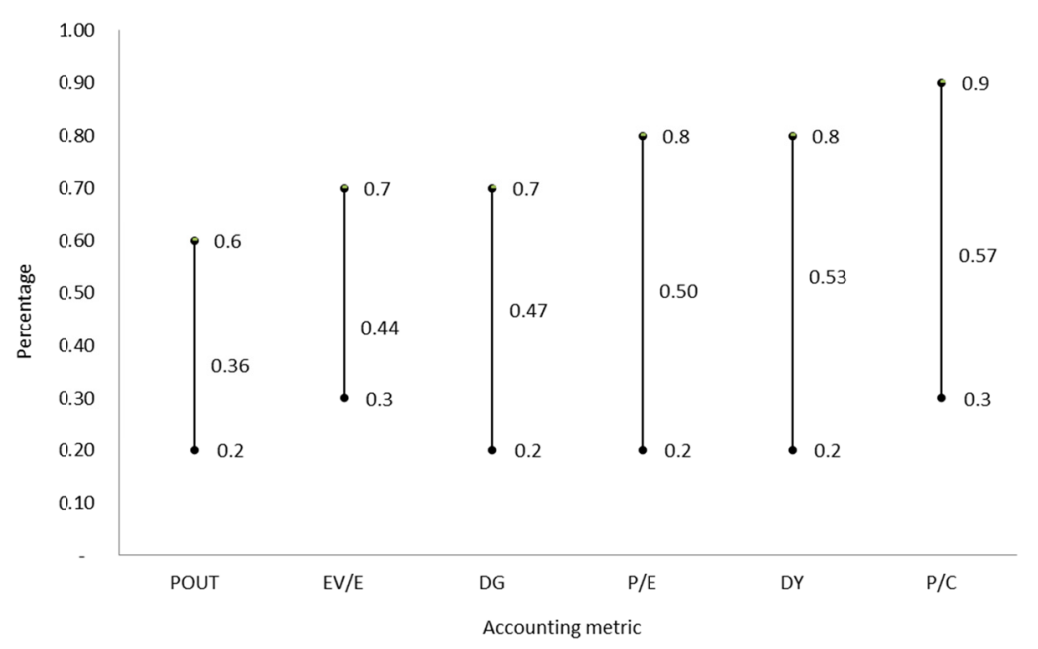

Figure 1. Degree of overlapping in holdings relative to book-to-market portfolio

Note. This figure depicts the degree of overlapping holdings across the tested metrics relative to the book-to-market value ranked portfolio. We chose the B/MV metric as our benchmark given its popularity amongst academics and practitioners. Metrics are ranked in ascending order from the lowest average overlap to the highest. Analysis is based on a period from 1988-2012.

We observe a similar pattern, although not statistically significant, where value premia are on average largest in December and January. We report value premia ranging between $0.08 \%$ for P/E and $1.77 \%$ for DG in January; only DY shows a negative premium of $0.23 \%$. With respect to December value premia are positive across all metrics ranging between $0.14 \%$ for DG and $1.92 \%$ for P/E, where $5 / 7$ are statistically significant. Seasonality in stock returns has been confirmed by various studies, Wachtel (1942) being the first to document the 'January effect'. Clare et al. (1995) provide evidence for stock returns in the UK to show a seasonal increase in January, April and December and a decline in September between 1955-1990. More recently Zhang and Jacobsen (2012) confirm previous findings on a large scale sample of 300 years of UK stock returns and extend the effect towards July and October returns also being largely negative. Therefore, our findings are in line with previous research on the January effect amongst stock returns. With respect to value premia, as tested in this study, Jacobsen et al. (2005) also report large parts of the value premia of size, book-to-market, earnings-over-price and cash flow-over-price to be driven by the January effect. Same is observable for our sample, where all metrics show statistically significant value premia in either or both December and January.

Besides, we take a closer look at portfolio reallocation in Panel B of Table 6 to see what percentage of companies are excluded or included per year. We are interested in whether portfolios which are generating higher returns also experience a higher degree of shift in their allocation. Furthermore, we want to evaluate if there is a 
significant difference in reallocation between growth and value portfolios. We report an average reallocation of $56 \%$ and $59 \%$ for value and growth portfolios, respectively. Whilst the cross-metric difference is low, single metrics show significant differences. We observe statistically significant differences in reallocation in favour of DG, EV/E and P/C value portfolios of $6.24 \%, 5.82 \%$ and $11.65 \%$, respectively. Interestingly there is no direct link observable with respect to our regression results, however, referring back to Table 2 we find these portfolios to have the highest Sharpe ratios across the set of tested metrics. Thereon, we conclude that return is not driven by higher reallocation, but rather by larger year-on-year consistency in the metric specific ranking of firms. This should also have a positive effect on portfolios transaction costs-as reallocation is essentially the portfolios annual turnover-thereby widening the return gap between these three portfolios and the alternative tested metrics.

\subsection{Portfolio Holdings}

In a final step we are interested in the degree of overlapping portfolio holdings. Thereon, we analyse the degree of overlapping observable for our tested accounting metrics relative to our book-to-market value portfolio. We choose the B/MV portfolio as our benchmark, given it's the most commonly applied and well known metric for ranking portfolios. Figure 1 presents both the lowest/highest and average degree of overlapping across the 25 years. Metrics are ranked in ascending order with POUT showing on average lowest portfolio overlapping and $\mathrm{P} / \mathrm{C}$ the highest degree of overlapping in relation to the $\mathrm{B} / \mathrm{MV}$ portfolio. Once more, portfolios formed according to POUT appear to deviate largely from the alternative metrics by showing a very low on average degree of overlapping in its holdings. This can again be seen as evidence for the ambiguous categorisation of value stocks being either stocks with a high or low payout ratio. Overall, we observe the-amongst minority investors-more popular and commonly considered equity value multiples (e.g., P/E, P/C and DY) to show a larger degree of overlapping with respect to the $\mathrm{B} / \mathrm{MV}$ benchmark, which is of the same class.

\section{Concluding Remarks}

We document statistically significant Jensen and Carhart alphas across all tested metrics. Particularly, metrics of recent attention show highest risk adjusted returns and Jensen alphas of $6.15 \%$ p.a. for EV/E, $5.25 \%$ for $\mathrm{P} / \mathrm{C}$ and $4.59 \%$ for DG. This indicates that more popular value metrics are exploited by market participants and show higher market betas across the full sample between 1988 until 2012. Therefore, providing evidence partially in favour of market efficiency. Against our initial hypothesis-and the results by Fama and French (2012)-we observe statistical and economically significant risk-adjusted outperformance of size restricted value portfolios.

Moreover, we show that value betas are generally higher than growth betas in bull markets and smaller in bear markets. These findings are consistent with Lakonishok et al. (1994) and reject the hypothesis of systematic risk being the source of the value premium as indicated by De Bondt and Thaler (1987) and Chopra et al. (1992). Consistent with our beta results, we report value portfolios to earn on average higher risk-adjusted returns compared to growth portfolios.

Additionally, we test for the general intuition of value stocks having historically shown low prices whereas growth stocks are expected to have received more investor attention; consequently, leading to price increases (Lakonishok et al., 1994). We analyse returns of value and growth stocks 12 -month pre- and post-rebalancing and find largely significant negative value premia before rebalancing and significantly positive after. Furthermore, we observe calendar effects in the form of the 'January effect' as well as lowest returns in September and October, which is in line with previous research (Jacobsen et al., 2005). Finally, we show statistically significant differences in portfolio turnover in favour of value portfolios, where turnover of value portfolio is more than 11 percentage points smaller per year compared to its growth counterpart.

Our results indicate favourable characteristics for value over growth portfolios even when the investment set is restricted to a small number of large cap stocks, as well as favourable characteristics of less prominent metrics like enterprise value-to-EBITDA and price-to-cash flow. Results for portfolios ranked according to firms payout ratio are mixed, however, we observe a tendency for dividend-based strategies-including dividend yield and dividend growth-to indeed offer strong benefits during phases of market downturn.

\section{References}

Andrade, S. C., \& Chhaochharia, V. (2012). Adding value to value: Is there a value premium among large stocks? Working Paper. http://dx.doi.org/10.2139/ssrn.2096310

Ang, A. (2002). Characterizing the ability of dividend yields to predict future dividends in log-linear present value models. Working Paper.

Arnott, R. D., \& Asness, C. S. (2003). Surprise! higher dividends = higher earnings growth. Financial Analyst 
Journal, 59(1),70-87. http://dx.doi.org/10.2469/faj.v59.n1.2504

Artmann, S., Finter, P., \& Kempf, A. (2012). Determinants of expected stock returns: Large sample evidence from the german market. Journal of Business Finance and Accounting, 39(5), 758-784. http://dx.doi.org/10.1111/j.1468-5957.2012.02286.x

Artmann, S., Finter, P., Kempf, A., Koch, S., \& Theissen, E. (2012). The cross-section of german stock returns: New data and new evidence. Schmalenbach Business Review, 64(1), 20-43.

Breig, C., \& Elsas, R. (2009). Default risk and equity returns: A comparison of the bank-based German and the U.S. financial system. Working Paper. http://dx.doi.org/10.2139/ssrn.1102441

Campbell, J., \& Shiller, R. (1988). Stock prices, earnings, and expected dividends. Journal of Finance, 43(3), 661-676. http://dx.doi.org/10.2307/2328190

Carhart, M. (1997, March). On persistence in mutual fund performance. Journal of Finance, 52(1), 57-82. http://dx.doi.org/10.2307/2329556

Chan, L., \& Lakonishok, J. (2004). Value and growth investing: Review and update. Financial Analyst Journal, 60(1), 71-84. http://dx.doi.org/10.2469/faj.v60.n1.2593

Chan, L., Hamao, Y., \& Lakonishok, J. (1991). Fundamentals and stock returns in Japan. Journal of Finance, 46, 1739-1764. http://dx.doi.org/10.2307/2328571

Chan, L., Jegadeesh, N., \& Lakonishok, J. (1996). Momentum strategies. Journal of Finance, 5, 1681-1713. http://dx.doi.org/10.2307/2329534

Chandy, P. R., Sarkar, S. K., \& Tripathy, N. (2004). Empirical evidence on the effects of delisting from the national market system. Journal of Economics and Finance, 28(1), 46-55. http://dx.doi.org/10.1007/BF02761454

Chaves, D. B., \& Arnott, R. (2012). Rebalancing and the value effect. Journal of Portfolio Management, 38(4), 59-74. http://dx.doi.org/10.2139/ssrn.1982735

Chiang, K. (2008). High dividend yield does predict lower dividend growth: A natural experiment. Working Paper. http://dx.doi.org/10.2139/ssrn.1107192

Chopra, N., Lakonishok, J., \& Ritter, J. R. (1992). Measuring abnormal performance: do stocks overreact. Journal of Financial Economics, 31, 235-268. http://dx.doi.org/10.1016/0304-405X(92)90005-I

Chou, J., Das, P. K., \& Rao, S. U. (2011). The value premium and the January effect. Managerial Finance, 37(6), 517-536. http://dx.doi.org/10.1108/03074351111134727

Clare, A., Psaradakis, Z., \& Thomas, S. (1995). An analysis of seasonality in the U.K. equity market. Economic Journal, 105, 398-409. http://dx.doi.org/10.2307/2235499

Cochrane, J. H. (2008). The dog that did not bark: A defense of return predictability. Review of Financial Studies, 21(4), 1533-1575. http://dx.doi.org/10.1093/rfs/hhm046

Cooper, M., \& Gubellini, S. (2011). The critical role of conditioning information in determining if value is really riskier than growth. Journal of Empirical Finance, 18(2), 289-305. http://dx.doi.org/10.1016/j.jemp_n.2010.11.004

Daniel, K., \& Moskowitz, T. (2013). Momentum crashes. Working Paper. http://dx.doi.org/10.2139/ssrn.1914673

De Bondt, W., \& Thaler, R. (1987). Further evidence on investor overreaction and stock market seasonality. Journal of Finance, 42(3), 557-581. http://dx.doi.org/10.2307/2328371

Domiana, D., Loutonb, D., \& Mossmanc, C. (1998). The rise and fall of the dogs of the dow. Financial Services Review, 7, 145-159. http://dx.doi.org/10.1016/S1057-0810(99)00007-4

Engsted, T., \& Pedersen, T. Q. (2009). The dividend-price ratio does predict dividend growth: International evidence. CREATES Research Papers. http://dx.doi.org/10.1016/j.jemp_n.2010.01.003

Fama, E., \& French, K. (1992). The cross-section of expected stock returns. Journal of Finance, 47, 427-465. http://dx.doi.org/10.2307/2329112

Fama, E., \& French, K. (1998). Value versus growth: The international evidence. Journal of Finance, 53, 1975 1999. http://dx.doi.org/10.1111/0022-1082.00080

Fama, E., \& French, K. (2002). Testing trade-off and pecking order predictions about dividends and debt. Review of Financial Studies, 15(1), 1-33. http://dx.doi.org/10.1093/rfs/15.1.1 
Fama, E., \& French, K. (2012, September). Size, value, and momentum in international stock returns. Journal of Financial Economics, 105(3), 457-472. http://dx.doi.org/10.1016/j.j_neco.2012.05.011

Fama, E., \& MacBeth, J. (1973). Risk, return, and equilibrium: Empirical tests. Journal of Political Economy, 81(3), 607-636. http://dx.doi.org/10.1086/260061

Greenwald, B. C. N., Kahn, J., Sonkin, P. D., \& Van Biema, M. (2001). Value investing: From Graham to Buffett and beyond. Wiley Finance.

Hou, K., Karolyi, G., \& Kho, B. (2011). What factors drive global stock returns? Review of Financial Studies, 24, 2527-2574. http://dx.doi.org/10.1093/rfs/hhr013

Houge, T., \& Loughran, T. (2006). Do investors capture the value premium? Financial Management, 35(2), 5-19. http://dx.doi.org/10.1111/j.1755-053X.2006.tb00139.x

Hwang, S., \& Rubesam, A. (2013). A behavioral explanation of the value anomaly based on time-varying return reversals. Journal of Banking and Finance, 37(7), 2367-2377. http://dx.doi.org/10.1016/j.jbank_n.2013.01.030

Jacobsen, B., Mamun, A., \& Visaltanachoti, N. (2005). Seasonal, size and value anomalies. Working Paper. http://dx.doi.org/10.2139/ssrn.784186

Kothari, P., Shanken, J., \& Sloan, R. (1995). Another look at the cross-section of expected stock returns. Journal of Finance, 50(1), 185-224. http://dx.doi.org/10.2307/2329243

Lakonishok, J., Shleifer, A., \& Vishny, R. W. (1994). Contrarian investment, extrapolation and risk. Journal of Finance, 49, 1541-1578. http://dx.doi.org/10.2307/2329262

Li, X., Brooks, C., \& Miffre, J. (2009). The value premium and time-varying volatility. Journal of Business Finance \& Accounting, 36(9), 1252-1272. http://dx.doi.org/10.1111/j.1468-5957.2009.02163.x

Liu, J., Nissim, D., \& Thomas, J. (2007). Is cash flow king in valuations? Financial Analyst Journal, 63(2). http://dx.doi.org/10.2469/faj.v63.n2.4522

Liu, L., \& Zhang, L. (2008). Momentum profits, factor pricing, and macroeconomic risk. Review of Financial Studies, 21(6), 2417-2448. http://dx.doi.org/10.1093/rfs/hhn090

Lynch, A. (2001). Portfolio choice and equity characteristics: characterizing the hedging demands induced by

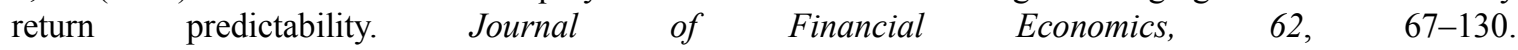
http://dx.doi.org/10.1016/S0304-405X(01)00074-5

Mulford, C. W., \& Jayko, J. (2007). Net income plus depreciation, operating cash flow and buildups in operating working capital. Technical Report, Georgia Institute of Technology.

Nance, D. R., Cli_ord, W., Smith, J., \& Smithson, C. W. (1993). On the determinants of corporate hedging. Journal of Finance, 48(1), 267-284. http://dx.doi.org/10.2307/2328889

Oertmann, P. (2000). Why do value stocks earn higher returns than growth stocks, and vice versa? Finanzmarkt und Portfoliomanagement, 14, 131-151.

Petkova, R. (2005). Do the Fama-French factors proxy for innovations in predictive variables? Journal of Finance, 61(2), 581-612. http://dx.doi.org/10.1111/j.1540-6261.2006.00849.x

Piotroski, J. D., \& So, E. C. (2012). Identifying expectation errors in value/glamour strategies: A fundamental analysis approach. Review of Financial Studies, 25(9), 2841-2875. http://dx.doi.org/10.1093/rfs/hhs061

Rinne, E., \& Vahamaa, S. (2011). The 'dogs of the dow' strategy revisited: Finnish evidence. European Journal of Finance, 17, 451-469. http://dx.doi.org/10.1080/1351847X.2010.544951

Schlag, C., \& Wohlschieff, V. (1997). Is beta dead? results for the German stock market. Working Paper.

Schwert, W. (2003). Anomalies and market effciency. In G. Constantinides, M. Harris, \& R. Stulz (Eds.), Handbook of the economics of finance (Vol. 1, pp. 939-974). Elsevier. http://dx.doi.org/10.1016/S1574-0102(03)01024-0

Stehle, R. (1997). Der size-effekt am deutschen aktienmarkt. Zeitschrift für Bankrecht und Bankwirtschaft, 9, 237-260.

Subramanyam, K. R., \& Venkatachalam, M. (2007). Earnings, cash flow, and ex-post intrinsic value of equity. Accounting Review, 82(2), 457-481. http://dx.doi.org/10.2308/accr.2007.82.2.457

Wachtel, S. (1942). Certain observations on seasonal movements in stock prices. Journal of Business, 15, 184- 
193. http://dx.doi.org/10.1086/232617

Walkshäusl, C., \& Lobe, S. (2010). Fundamental indexing around the world. Review of Financial Economics, 19(3), 117-127. http://dx.doi.org/10.1016/j.rfe.2010.02.001

Wallmeier, M. (2000). Determinanten erwarteter renditen am deutschen aktienmarkt-eine empirische untersuchung anhand ausgewählter kennzahlen. $Z F B F, 52,27-57$.

Zhang, C., \& Jacobsen, B. (2012). Are monthly seasonals real? a three century perspective. Review of Finance, $17(5), 1-43$.

\section{Copyrights}

Copyright for this article is retained by the author(s), with first publication rights granted to the journal.

This is an open-access article distributed under the terms and conditions of the Creative Commons Attribution license (http://creativecommons.org/licenses/by/3.0/). 